\title{
Mineral pigments at Huaca Tacaynamo (Chan Chan, Peru)
}

Pigmentos minerales en la Huaca Tacaynamo (Chan Chan, Perú)

Les pigments minéraux à la huaca Tacaynamo, Chan Chan, Pérou

William E. Brooks, Víctor Piminchumo, Héctor Suárez, John C. Jackson y John P. McGeehin

\section{OpenEdition}

\section{Journals}

Edición electrónica

URL: http://journals.openedition.org/bifea/2957

DOI: $10.4000 /$ bifea.2957

ISSN: 2076-5827

Editor

Institut Français d'Études Andines

Edición impresa

Fecha de publicación: 1 diciembre 2008

Paginación: 441-450

ISSN: 0303-7495

\section{Referencia electrónica}

William E. Brooks, Víctor Piminchumo, Héctor Suárez, John C. Jackson y John P. McGeehin, « Mineral pigments at Huaca Tacaynamo (Chan Chan, Peru) », Bulletin de l'Institut français d'études andines [En línea], 37 (3) | 2008, Publicado el 01 junio 2009, consultado el 26 noviembre 2020. URL : http:// journals.openedition.org/bifea/2957 ; DOI : https://doi.org/10.4000/bifea.2957

\section{(c) $(1)$}

Les contenus du Bulletin de l'Institut français d'études andines sont mis à disposition selon les termes de la licence Creative Commons Attribution - Pas d'Utilisation Commerciale - Pas de Modification 4.0 International. 


\title{
Mineral pigments at Huaca Tacaynamo (Chan Chan, Peru)
}

\author{
William E. Brooks* \\ Víctor Piminchumo ${ }^{* *}$ \\ Héctor Suárez ${ }^{* *}$ \\ John C. Jackson ${ }^{* * *}$ \\ John P. McGeehin ${ }^{* * *}$
}

\begin{abstract}
X-ray diffraction analyses of five samples of pigments from a recently excavated mural at the archaeological site of Huaca Tacaynamo, a part of the Chan Chan archaeological complex, northern Peru, show that minerals related to metal occurrences known to have been exploited by ancient Andeans were also used as pigments. These minerals include: atacamite $\left[\mathrm{Cu}_{2} \mathrm{Cl}\left(\mathrm{OH}_{3}\right)\right]$ for green; azurite $\left[\mathrm{Cu}_{3}\left(\mathrm{CO}_{3}\right)_{2}(\mathrm{OH})_{2}\right]$ for blue; calcite $\left[\mathrm{CaCO}_{3}\right]$ for white; cinnabar $[\mathrm{HgS}]$ for red; and goethite $\left[\mathrm{HFeO}_{2}\right]$ for yellow. Woven plant material from Tacaynamo gave a calibrated, 2 sigma ${ }^{14} \mathrm{C}$ date of $\mathrm{AD} 1412-1614$; however, initial occupation of the site and painting of the murals may have been earlier.
\end{abstract}

Key words: cinnabar, mural, X-ray, diffraction, Chan Chan

\section{Pigmentos minerales en la Huaca Tacaynamo (Chan Chan, Perú)}

\section{Resumen}

Los análisis de difracción de rayos $x$ en 5 muestras de pigmentos de un mural, recientemente excavado en el sitio arqueológico de Huaca Tacaynamo — una parte del complejo de Chan Chan en el norte del Perú-, muestran ciertos minerales relacionados con presencias metálicas que, como se sabe, han sido

Geology and Environmental Science-5F2, George Mason University, 4400 University Drive, Fairfax, VA 22030. E-mail: webgeology@aim.com

** Instituto Nacional de Cultura, sede Trujillo (Perú).

${ }_{* * *}^{*}$ U.S. Geological Survey, 926A National Center, Reston, VA 20191. 
aprovechados por los antiguos habitantes de los Andes, también, como pigmentos. Estos minerales incluyen atacamita $\left[\mathrm{Cu}_{2} \mathrm{Cl}\left(\mathrm{OH}_{3}\right)\right]$ para el color verde; azurita $\left[\mathrm{Cu}_{3}\left(\mathrm{CO}_{3}\right)_{2}(\mathrm{OH})_{2}\right]$ para el azul; calcita $\left[\mathrm{CaCO}_{3}\right]$ para el blanco; cinabrio $[\mathrm{HgS}]$ para el rojo; y goetita $\left[\mathrm{HFeO}_{2}\right]$ para el amarillo. La datación de los tejidos a partir de materiales vegetales de Tacaynamo con el ${ }^{14} \mathrm{C}$ dio como resultado: AD 1412 1614. Sin embargo, la ocupación inicial del sitio y la pintura de los murales bien podría haber sido previas.

Palabras clave: cinabrio, fresco, rayos- $X$, difracciónChan Chan

\section{Les pigments minéraux à la huaca Tacaynamo, Chan Chan, Pérou}

\section{Résumé}

Les analyses de diffraction des rayons $X$ sur cinq échantillons de pigments d'une peinture murale récemment découverte sur le site archéologique de Huaca Tacaynamo - qui fait partie du complexe de Chan Chan, au nord du Pérou - indiquent la présence de minéraux connus pour avoir servi de pigments aux anciens habitants des Andes. Ces minéraux sont l'atacamite $\left[\mathrm{Cu}_{2} \mathrm{Cl}\left(\mathrm{OH}_{3}\right)\right]$ pour la couleur verte; l'azurite $\left[\mathrm{Cu}_{3}\left(\mathrm{CO}_{3}\right)_{2}(\mathrm{OH})_{2}\right]$ pour le bleu; la calcite $\left[\mathrm{CaCO}_{3}\right]$ pour le blanc; le cinabre $[\mathrm{HgS}]$ pour le rouge; et la goethite $\left[\mathrm{HFeO}_{2}\right]$ pour le jaune. Le matériel tissé d'origine végétale retrouvé à Tacaynamo a donné un calibrage de 2 sigma ${ }^{14} \mathrm{C}$ avec une date de $\mathrm{AD} 1412-1614$; cependant, la première occupation du site et les peintures murales pourraient bien être antérieures.

Mots clés : cinabre, murale, radiographie, diffraction, Chan Chan

\section{INTRODUCTION}

Mineral pigments used in ancient societies are of interest to archaeologists, art historians, chemists and geologists. Excavations in Egypt, Greece, Italy, Morocco, Peru and elsewhere show that mineral pigments or «earth colors» were used to decorate murals, ceramics, thrones, tiles and inlaid mosaics and as a preservative. Because of their stability, and in some cases, toxicity, mineral pigments have withstood biological activity, exposure, volcanic eruptions and weathering. Some mineral pigments were used with little preparation directly from their geological sources and these include realgar (AsS) for reddish-orange, iron oxides $\left(\mathrm{Fe}_{2} \mathrm{O}_{3}\right.$ ) or cinnabar $(\mathrm{HgS})$ for red, coal or manganese minerals $(\mathrm{Mn})$ for black, and calcite $\left(\mathrm{CaCO}_{3}\right)$ or kaolin $\left[\mathrm{Al}_{2} \mathrm{Si}_{2} \mathrm{O}_{5}(\mathrm{OH})_{4}\right]$ for white. Other pigments were more complex, such as Egyptian blue (blue frit) which was prepared by heating silica $\left(\mathrm{SiO}_{2}\right)$, malachite $\left[\mathrm{Cu}_{2}\left(\mathrm{CO}_{3}\right)\right.$ $(\mathrm{OH})_{2}$, and calcite $\left(\mathrm{CaCO}_{3}\right)$ (Farnsworth, 1951: 73).

In pre-contact Peru, the decorated murals at Huaca Tacaynamo and other wellknown archaeological sites such as Chan Chan (Pillsbury, 1993: 369), Illimo (Schaedel, 1978: 27), La Mina (Scott et al., 1998: 177), Pachacamac (Petersen, 1970: 18), and Paracas (Petersen, 1970: 17) show that ancient Andeans exploited mineral occurrences for industrial use, as pigments, in addition to the more well-known use of copper, gold, silver, platinum, and mercury for artisanal metalwork. Muelle \& Wells (1939: 27) correlated specific minerals to the colors that were produced and Bonavia (1985: 178) described the geologic occurrence of pigments, pigment production, storage, brush composition, painting techniques, and clays used as plaster. However, Bonavia (1985: 199) did not specify which minerals were used for the pigments and qualitative spectrographic analysis was used to indicate which elements were major, minor or trace components in the pigments. There 
was speculation that plant-based pigments similar to Maya blue, a plant-clay pigment that was used in pre-contact Central America, may have been used in Peru and Bonavia's data established that only unspecified mineral pigments were used for mural paints in ancient Peru (Bonavia, 1985: 179).

No information was found on the mineral or plant source of pigments used to decorate ancient Andean ceramics; however, petroleum seeps in southern Texas (USA) were exploited by the Karankawa and these seeps provided a reddish pigment for ceramic decoration (Ricklis, 1996: 101). Tar from northern Peru's petroleum seeps (Stothert, 1994: 344), which was used as glue, may also have been similarly used to provide a source of petroleum for ceramic decoration. Black, though not used at Tacaynamo, may have also been sourced from coal (Bonavia, 1985: 179), which is abundant in northern Peru (Brooks et al., 2004).

\section{HUACA TACAYNAMO}

Huaca Tacaynamo and nearby Huaca El Dragón, which is only a few hundred meters away, are located on the periphery of the larger Chimu archaeological complex of Chan Chan (Jackson, 2004: 299). The site is near Km 552 of the Panamerican Highway in Trujillo, in northern Peru. Wooden figures recovered from the site suggest a religious or funerary purpose of the site. Tacaynamo is bordered by an outer mural that outlines a rectangular courtyard where there are two superposed platforms and a ramp. The mural has polychromatic decoration (Iriarte 1976: 27; Ravines, 1981: 20) from which dozens of fragments, distinctly different from those sampled at the main site of Chan Chan, were recovered (Piminchumo, 2004: 6). Tacaynamo may have been first occupied as early as the Middle Horizon (AD 600-AD 1000) (Navarro, 1991: 52) or, alternatively, during Early Chimu time (AD 1000-AD 1100) and sporadic occupation probably lasted into the Colonial period (Jackson, 2004: 304).

\section{1. Mineral pigments}

Five samples of mineral pigments from the recently excavated mural at Tacaynamo were analyzed by $x$-ray diffraction methods in order to identify the minerals. The palette of the Tacaynamo muralists included:

- Green-Atacamite (fig.1) is a dark green, copper halide mineral $\left[\mathrm{Cu}_{2} \mathrm{Cl}(\mathrm{OH})_{3}\right]$ that is vitreous and soft (hardness of 3-3.5). It is a common mineral in arid climates, especially where copper minerals are exposed to oxidation, and may be a useful field guide for minerals exploration. Petersen (1970: 6) lists more than 20 occurrences for atacamite.

- Blue-Azurite (fig. 2) is a deep blue, copper carbonate mineral $\left[\mathrm{Cu}_{3}\left(\mathrm{CO}_{3}\right)_{2}(\mathrm{OH})_{2}\right]$ that is vitreous, soft (hardness 3.5-4), and may be found in the alteration zones near porphyry copper deposits. Pliny describes a blue pigment that was used in medicine to give nourishment to the hair and azurite was identified on murals in China that date to the Ming dynasty (Rapp, 2002: 210). Petersen (1970: 4) only lists a few of the large number of copper occurrences in Peru (Ministry of Energy and Mines, 1999: 14) which would indicate that the mineral is widespread.

- White-Calcite (fig. 3) is a very common calcium carbonate mineral $\left[\mathrm{CaCO}_{3}\right]$ that may occur in veins associated with many types of mineral occurrences. Other sources of calcite include limestone, chalk, or mollusk shells (Rapp, 2002: 213). Typically, calcite is white, soft (hardness of 3), and could easily be prepared for pigment use. This mineral 
may also have been obtained from calcining seashells and was an integral part of coca use in the ancient Andes.

- Red-Cinnabar (fig. 4) is a red mercury sulfide mineral [HgS] that may be associated with hot springs or shallow epithermal mineral deposits worldwide. Both for size and historical importance, the most well-known deposits include Almaden in Spain, Huancavelica in Peru, and Idrija in Slovenia. Cinnabar is soft (hardness of 2-2.5) and is the common ore mineral of mercury. A minimum of 20 cinnabar occurrences are known in Peru (Petersen, 1970: 18) and the occurrences at Huancavelica, one of the world's largest and most well-known producers of mercury (Arana, 1901: 25; Yates et al., 1951: 1), are the most likely source of the cinnabar that was used in ancient Peru. There are cinnabar sources throughout the Andes and it is possible that sources in Ecuador, which are not as well known but are closer to northern Peru, also may have been exploited (Chacón, 1986: 25; Truhan et al., 2005: 201).

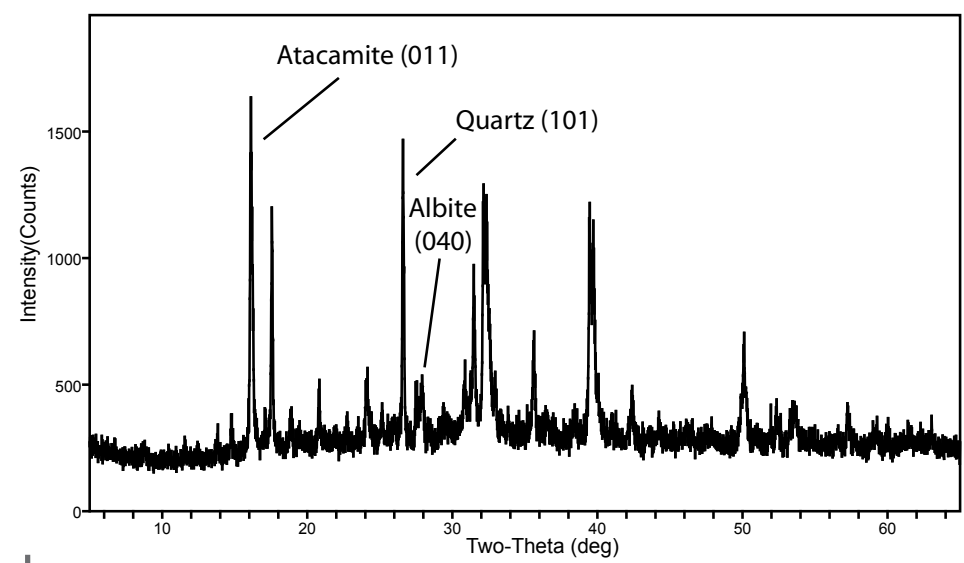

Figure 1 - Atacamite x-ray diffraction pattern with quartz and feldspar

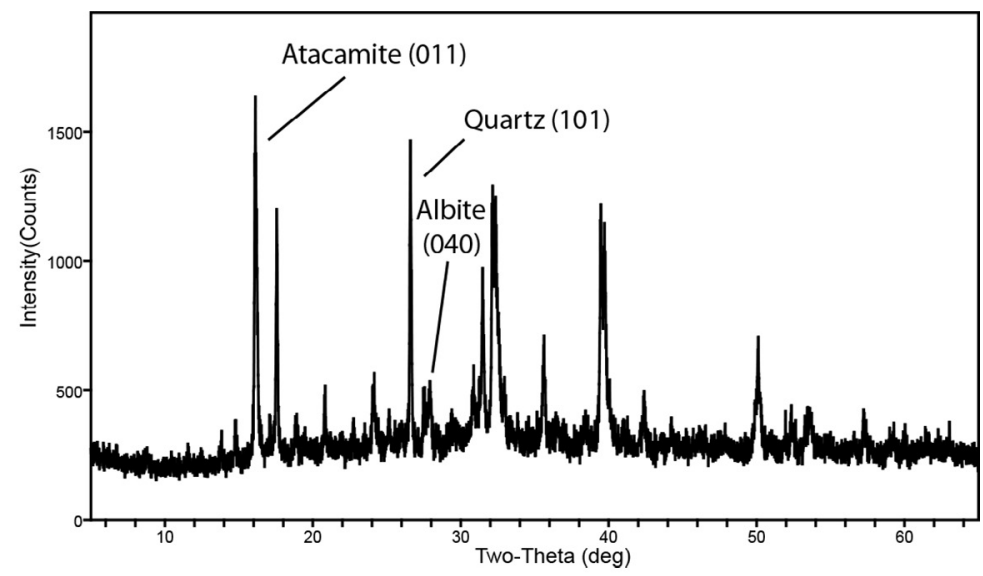

Figure 2 - Azurite x-ray diffraction pattern with quartz and minor atacamite 


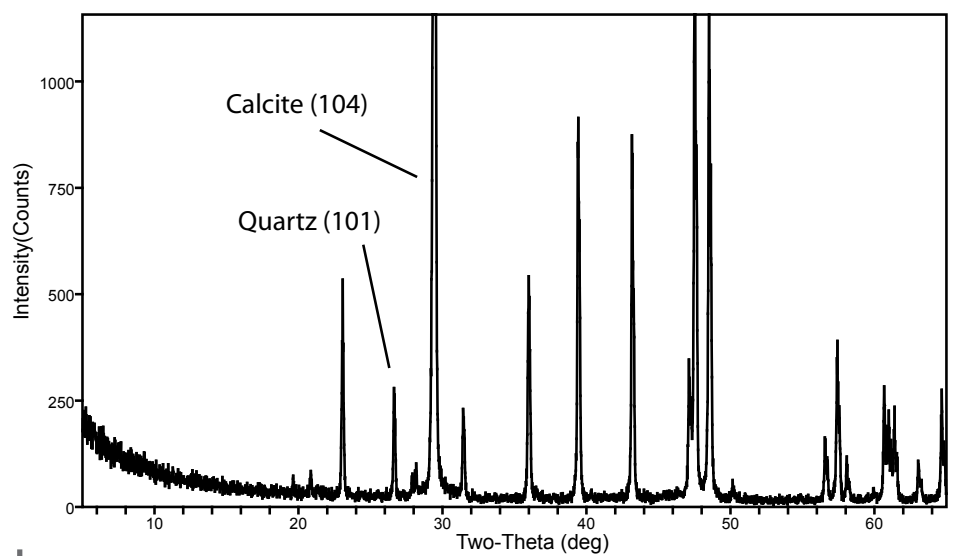

Figure 3 - Calcite x-ray diffraction pattern

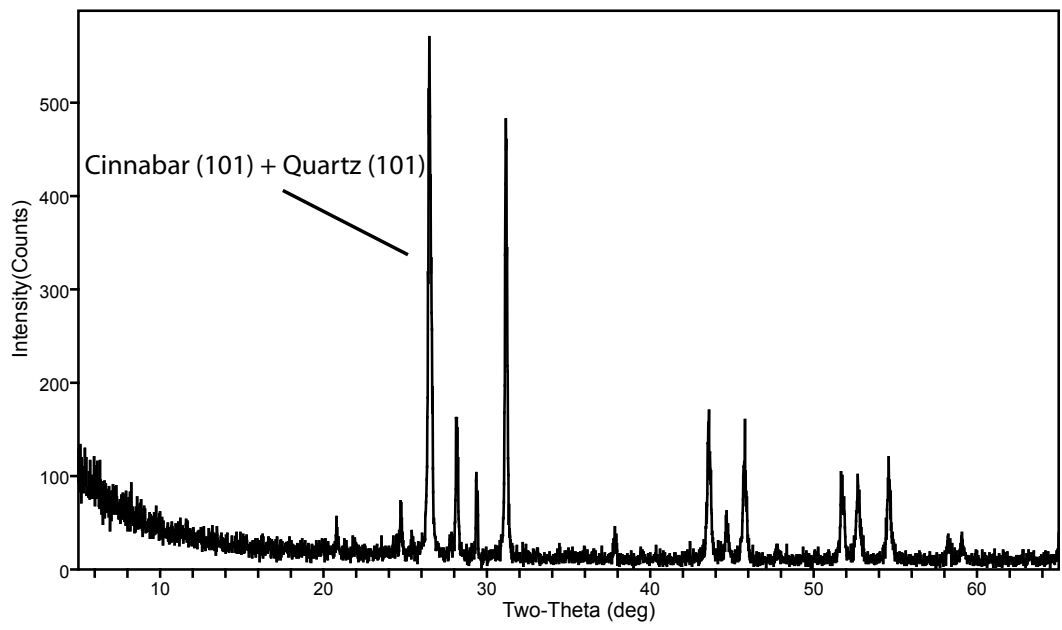

Figure 4 - Cinnabar x-ray diffraction pattern with quartz

In Peru, powdered cinnabar was used to decorate gold masks during the Formative Period (400-1000 B.C.) (De Lavalle, 1992: 36); as a mural pigment (Petersen, 1970: 16; Brooks et al., 2006); for sacrificial ceremonies (Petersen, 1970: 6); for warrior's bodies; as a cosmetic for the elite Inca women (Brown, 2001: 470); and as a body paint for corpses (Shimada \& Griffin, 2005: 83) and other funeral preparations (Maravelaki-Kalaitzaki \& Kallithrakas-Kontos, 2003; J. Verano, anthropologist, oral commun., 2006).

Mercury was used by the Moche ( 100 B.C.-A.D. 750) in northern Peru to amalgamate placer gold (Larco Hoyle, 2001: 137) and for the production of artisanal goldcraft (Kaufmann Doig, 1978: 747). At Huancavelica, mercury was recovered from drainages and may have been retorted from cinnabar (Petersen, 1970). Whether or not the ancient Andeans retorted cinnabar for mercury is controversial; however, retorts have been found near the mines at Huancavelica (K. Brown, professor, Brigham Young University, written 
commun., May 9, 2003). Only 15 kilometers from the mines at Huancavelica is Atalla, an archaeological site which was an ancient cinnabar pigment production center (Burger \& Matos, 2002: 11).

As did the ancient Romans, the Inca recognized the health hazards of mercury and that exposure to mercury and cinnabar during mining and retorting would cause the ancient miners «to shake and lose their senses» and, consequently, the use of mercury by the Inca declined (Larco Hoyle, 2001: 135). Perhaps its toxicity was also understood in other parts of the ancient world where cinnabar was used as a preservative to keep fine silks intact (Srinivasan \& Ranganathan, 2004). Powdered cinnabar is now known to be toxic (Sax, 1984, 1: 756).

Danger, eroticism, life, nobility, or woman's role in reproduction may be symbolized by and associated with red coloring. Yet, despite the availability of a variety of reds that included insect-derived cochineal, feathers, plant-derived bixa (or bija) from the Bixa orellana (Petersen, 1970: 6), and mineral-derived cinnabar, goethite, hematite, and jasper, ancient Peruvians apparently selectively used powdered cinnabar for funeral preparations (Shimada \& Griffin, 2005: 83; J. Verano, anthropologist, oral commun., 2006). Cinnabar has also been found in funeral contexts in Greece and Spain (Maravelaki-Kalaitzaki \& KallithrakasKontos, 2003). Therefore, in the mortuary process in ancient Peru, cinnabar may have had, at the least, a dual role, first, as a preservative because of its toxicity and, second, the lifeover-death or life-giving symbolism suggested by its blood-red color.

- Yellow-Goethite (fig. 5) is a hydrated iron oxide mineral $\left[\mathrm{HFeO}_{2}\right]$ that was used for yellow-brown or yellow ochre. It is a very common mineral that may be yellow, brown, to black and has a hardness of 5-5.5 and also may be used as an ore of iron. In some mineral occurrences, iron may be released from the weathering of pyrite (FeS) which then becomes oxidized.

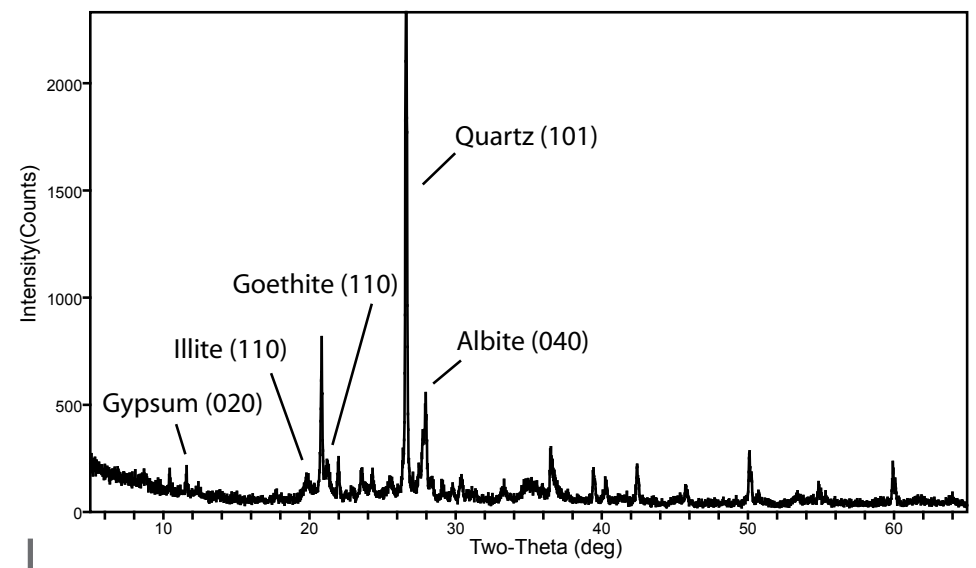

Figure 5 - Goethite x-ray diffraction pattern with quartz, feldspar, and illite 
The binder used for the pigments at Tacaynamo is unknown. Egg white, which is known to have been used as a binder in Europe, was available from nesting sea-birds on the nearby Guanapes Islands or from any of the other «guano» islands along the Peruvian coast (Brooks et al., 2004). Pre-contact artifacts found in the guano, which is up to $40 \mathrm{~m}$ thick, and scenes on ceramics show that the guano islands were exploited for the fertilizer and perhaps the sea-bird eggs were also collected. There is the possibility that domestic fowl may also have provided another source of egg white (K. Bruhns, professor, written commun., 2007).

\section{1. $2 .{ }^{14} \mathrm{C}$ date}

Woven plant material was obtained from Huaca Tacaynamo for geochronology and a calibrated ${ }^{14} \mathrm{C}$ date on this material gave a 2 sigma date of AD 1412-1614 (fig. 6). This date does not imply the age of the murals or initial occupation of the site.

Archaeological evidence indicates initial occupation of the site may have been in the final stages of the Middle Horizon (AD 600-AD 1000) (Navarro, 1991: 52). Brick morphology indicates that construction of Tacaynamo may have been later, Early Chimu or roughly AD 1000-1100 (Jackson, 2004: 304). Therefore, the ${ }^{14} \mathrm{C}$ date provides an upper limit that indicates that Tacaynamo was used and reused for approximately $\sim 1000$ years (when compared to data from Navarro, 1991) or 600 years (when compared to data from Jackson, 2004). Regardless of the initial occupation of the site, the ${ }^{14} \mathrm{C}$ date indicates that Tacaynamo was apparently in use, at least until the arrival of the Europeans. Comparing inferred, nonisotopic dates from archaeological studies with ${ }^{14} \mathrm{C}$ is inherently problematic; however, in this case, the ${ }^{14} \mathrm{C}$ date is especially useful because it expands and anchors the upper limits of occupation of Tacaynamo.

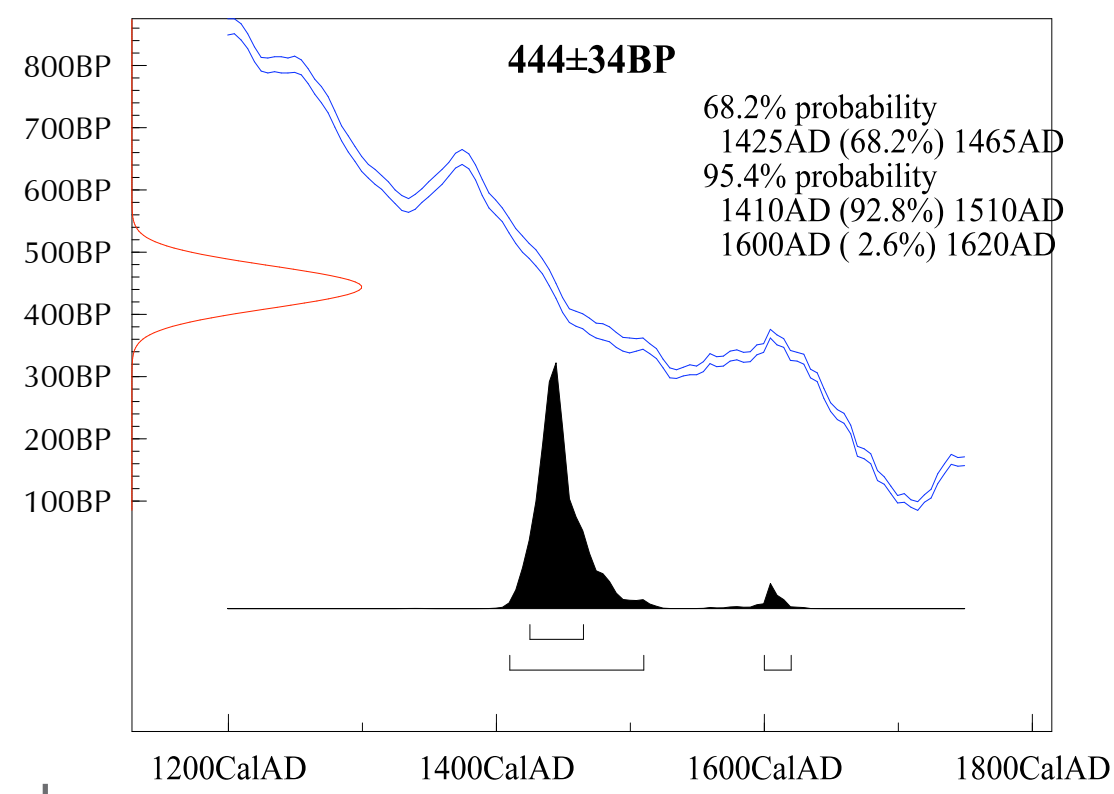

Figura 6 - Radiocarbon determination on woven plant material from Huaca Tacaynamo 


\section{3. Pigments and society}

The use of mineral pigments has been well-documented in Europe and Asia. Cinnabar, Egyptian blue, and malachite were some of the pigments applied to a marble throne in the Tomb of Eurydice, Vergina, Greece, that dates to 340 BC (Kakoulli et al., 2001). Realgar, cinnabar, azurite, and lead from galena were processed and used as mineral pigments during the Roman era (Windhaven Guild, 2004) to decorate tiles in Roman villas in Morocco. In the 700s, azurite, cinnabar, goethite, and malachite were used to illuminate the Book of Kells in Ireland (Windhaven Guild, 2004) and in the 1600s, the Dutch painter, Vermeer, used cinnabar, yellow ochre, and lead oxide for flesh tones. Arsenic provided the green for Scheele's green, a pigment used in wallpaper in the late 1700s (Jones \& Lealingham, 1982: 626; Lewin et al., 1982: 627). Some of the same types of mineral pigments in use at Tacaynamo, in particular cinnabar, were also in use in Europe from the 1300s until the 1900s (Windhaven Guild, 2004).

In some old Italian paintings, skies that were originally blue are now green due to the alteration of azurite, a blue mineral used for pigment. And, in Japan, lead oxide ( $\mathrm{PbO})$ obtained from galena was used to provide a striking white, but toxic, makeup for geishas.

Cinnabar ( $\mathrm{HgS}$ ) has been widely used for rouge, tattoos, warpaint, and for the «bindi» forehead symbol used in Hindu society (Srinivasan \& Ranganathan, 2004). Researchers found that cinnabar was one of the mineral pigments used on the frescoes that were later buried by ash from volcanic eruptions at Pompeii (Lorenzi, 2004).

The white pigment used in modern makeup, paints, sunscreen, or on candies and other foods is titanium dioxide obtained from the mineral rutile $\left(\mathrm{TiO}_{2}\right)$ or ilmenite $\left(\mathrm{FeTiO}_{3}\right)$. In 2005, for example, United States' production of $\mathrm{TiO}_{2}$ pigment was 1300000 metric tons (t) (Gambogi, 2005) and in 2004, U.S. production of iron oxide pigment was 85000 t valued at $\$ 77$ million (Potter, 2004). Therefore, whether for art applications or industrial use, consumption of mineral pigments is tied to the needs of a complex ancient or modern society.

\section{DISCUSSION}

Mineral occurrences were exploited not only for their metals but also for pigments for artistic and industrial use. Sourcing the Tacaynamo pigments is inherently difficult due to the large number of mineral occurrences in the region, lack of a geochemical database for comparison, and destruction of the original outcrop from ancient, colonial, or modern mining. For example, Huancavelica is the most well known cinnabar occurrence in Peru and is but one of numerous occurrences listed by Petersen (1970: 18). There are probably many other cinnabar occurrences associated with hot springs or the abundant epithermal mineral deposits in the Andean cordillera that may have been exploited. Similarly, there are at least 20 atacamite localities and goethite is a ubiquitous alteration product associated with epithermal systems throughout the Andes. 


\section{Referencias citadas}

ARANA, P. P., 1901 - Las minas de azogue del Perú; Lima: Imprenta El Lucero.

BONAVIA, D., 1985 - Mural painting in ancient Peru, 224 p.; Bloomington: Indiana University Press.

BROOKS, W. E., KENT, J. D. \& WILLETT, J. C., 2004 - Mineral, energy, and fertilizer resources of the north coast of Peru, perspective from the Santa Rita B archaeological site; U.S. Geological Survey Open File Report 2004-1024 < http://pubs.usgs.gov/ of/2004/1024/index.html>.

BROOKS, W. E., PIMINCHUMO, V., SUÁREZ, H., JACKSON, J. C. \& MCGHEEHIN, J. P., 2006 - Mineral pigments from Tacaynamo (Chan Chan, northern Peru). Geological Society of America, 38(7): 233.

BROWN, K.W., 2001 - Worker's health and colonial mercury mining at Huancavelica (Peru). The Americas. The Academy of American Franciscan History, 57(4): 467-496.

BURGER, R. \& MATOS, R., 2002 - Atalla, a center on the periphery of the Chavin horizon. Latin American Antiquity, 13(2): 10-25.

CHACÓN, Z. J., 1986 - Historia de la minería en Cuenca, 125 p.; Cuenca: Instituto de Investigaciones Sociales, Universidad de Cuenca.

DE LAVALLE, J. A., 1992 - Oro del antiguo Perú, 322 p.; Lima: Banco de Crédito.

FARNSWORTH, M. A., 1951 - Ancient pigments. Journal of Chemical Education, 28: 72-76.

GAMBOGI, J., 2005 - Titanium; U.S. Geological Survey Minerals Yearbook < http:// minerals.usgs.gov>.

IRIARTE, F., 1976 - Arquitectura y decoración mural en Huaca Tacaynamo, 52 p.; Lima: Dirección Universitaria de Investigación, Universidad Nacional Federico Villarreal. Cuadernos de Trabajo.

JACKSON, M. A., 2004 - The Chimu sculptures of Huacas Tacaynamo and El Dragón, Moche Valley, Peru. Latin American Antiquity, 15(3): 298-322.

JONES, D. E. \& LEALINGHAM, K. W., 1982 - Arsenic in Napoleon's wallpaper. Nature, 299: 626-627.

KAKOULLI, I., KOTTARIDOU, A. \& MINOS, N., 2001 - Materials and technologies of ancient monument paintings, analysis of the painted throne from the Tomb of Eurydice, Vergina; Archaeometry Issues in Greek Prehistory and Antiquity <http:// www.archaeometry.gr/oldv/publication/sybosio/index-eng.htm > .

KAUFMANN DOIG, F., 1978 - Manual de arqueología peruana, 800 p.; Lima.

LARCO HOYLE, R., 2001 - Los Mochicas, t. II, 350 p.; Lima: Museo Arqueológico Rafael Larco Herrera.

LEWIN, P. K., HANCOCK, R. G. \& VOYNOVICH, P. A., 1982 - Napoleon Bonaparte, no evidence of chronic arsenic poisoning. Nature, 299: 627-628.

LORENZI, R., 2004 - Pompeii artists painted the town red < http://www.abc.net.au>.

MARAVELAKI-KALAITZAKI, N. A. \& KALLITHRAKAS-KONTOS, N. P., 2003 - Cinnabar find in Cretan Hellenistic tombs. Preservative or for cosmetic purposes? $4^{\text {th }}$ Symposium on Archaeometry Greece, May 28-31; Athens. Available online at <http://www. archaeometry.gr/symposium2003>.

MINISTRY OF ENERGY AND MINES, 1999 - Atlas of mining and energy in Peru, 111 p.; Lima: Ministry of Energy and Mines.

MUELLE, J. C. \& WELLS, R., 1939 - Las pinturas del templo de Pachacamác. Revista del Museo Nacional, 8(2): 265; Lima. 
NAVARRO, H., 1991 - Nuevas evidencias arqueológicas en la Huaca Tacaynamo, un sitio Chimú en el Valle de Moche. Revista del Museo de Arqueología, 2: 49-64; Lima.

PETERSEN, G., 1970 - Minería y metalurgia en el antiguo Perú. Arqueológicas, 12: 140; Lima: Museo Nacional de Antropología y Arqueología.

PILLSBURY, J., 1993 - Sculpted friezes of the Empire of Chimor, 450 p.; New York: Columbia University. PhD dissertation.

PIMINCHUMO, V., 2004 - Nuevos descubrimientos en Chan Chan, conjunto Tschudi y Huaca Tacaynamo. Identidades. Guía Turística y Comercial, 1(4): 6-7; Trujillo.

POTTER, M. J., 2004 - Iron oxide pigments; U.S. Geological Survey Minerals Yearbook $<$ http://minerals.usgs.gov $>$.

RAPP, G., 2002 - Archaeomineralogy, 326 p.; New York: Springer.

RAVINES, R., 1981 - Chan Chan, metrópoli Chimú, 28 p.; Lima: Instituto de Estudios Peruanos, Instituto de Investigación Tecnológica Industrial y de Normas Técnicas.

RICKLIS, R. A., 1996 - The Karankawa Indians of Texas, 237 p.; Austin: University of Texas Press.

SAX, N. I., 1984 - Dangerous properties of industrial minerals, 3124 p.; New York: Van Nostrand Co.

SCHAEDEL, R. P., 1978 - The Huaca Pintada of Illimo. Archaeology, 31(1): 27-37.

SCOTT, D. A., DOUGHTY, D. H. \& DONNAN, C. B., 1998 - Moche wallpainting pigments from La Mina (Jequetepeque, Peru). Studies in Conservation, 43: 177-182.

SHIMADA, I. \& GRIFFIN, J. A., 2005 - Precious metal objects of the Middle Sican. Scientific American, 15(1): 80-89.

SRINIVASAN, S. \& RANGANATHAN, S., 2004 - Metallurgical heritage of India < http:// metalrg.iisc.ernet.in/ wootz/heritage/Heritage.htm > .

STOTHERT, K. E., 1994 - Early petroleum extraction and tar-boiling in coastal Ecuador. In: In Quest of Mineral Wealth, Aboriginal and Colonial Mining and Metallurgy in Spanish America (A. K. Craig \& R. C. West, eds.): 343-354; Louisiana: Department of Geography and Anthropology, Louisiana State University.

TRUHAN, D. L., BURTON, J. H. \& BRUHNS, K. O., 2005 - El cinabrio en el mundo Andino. Revista de Antropología, 18: 193-205; Cuenca: La Casa de La Cultura Ecuatoriana Benjamín Carrión.

WINDHAVEN GUILD, 2004 - Natural pigment watercolors <www.baronyofwindhaven.org>.

YATES, R. G., KENT, D. F. \& FERNÁNDEZ, J., 1951 - Geology of the Huancavelica quicksilver district. U.S. Geological Survey Bulletin, 975-A: 1-45. 